\title{
シェル・アンド・チューブ式熱交換器の過渡特性*
}

\author{
河合素直・町山忠弘・小泉睦男 \\ 早稲田大学大学院早秒田大学理工学研究所 早稻田大学理工学部 \\ 東京都新宿区喜久井町
}

(昭和 41 年 2 月 4 日受付)

\section{Experimental Study on the Transient Performance \\ of Shell and Tube Type Heat-Exchanger}

\author{
Sunao Kawai*, Tadahiro Machiyama** and Mutsuo Korzumi* \\ $\left(\begin{array}{l}* \text { Faculty of Science and Engineering, Waseda University, Shinjuku-ku, Tokyo } \\ \text { ** Science Engineering Research Laboratory, Waseda University, ditto }\end{array}\right.$
}

(Received February 4, 1966)

From the view point of control technique, many studies on the transient performance of heatexchanger were reported. In most of them temperature is regarded as the input and output variables. But the fluid temperature is seldom handled as manipulated variable. Generally in actual cases, flow-rate of fluid is manipulated to control the output temperature.

The authors tried to describe the transient performance in the actual situations by assuming the flow-rate as manipulated variable and the output temperature as controlled variable.

In this paper, some experimental results and theoretical considerations on the shell \& tube type heat-exchangers are reported. The considerations to describe the transient performance are based on the actual construction factors of the heat-exchanger and static characteristics derived by experiments and theoretical calculation.

\section{1. むえがき}

各種の装置工業に和沙る熱交換器の用途・構造はさ わめて多岐にわたっている、筆者らは熱交換器に関す る非定常特性を制御工学の技術的取扱いに耐えるよう な形で評価することに着手した。

従来の研究1) では各流体の温度変化に注目したもの が多い。乙かし熱交換器に関する制御問題では多くの 場合操作量は流体の流量であって, 温度は制御量また はその変化が外乱としての機能をもつ.したがって流 体の温度変化に注目した非定常特性の評価は活とんど 外乱に対する評価としての意義しかもたず，現実の問 題に当面して積極性を欠くららみがある. 流量変化に 対する温度の応答といら形でこの問題をとりあげるこ とは, 変係数の偏微分方程式を扱わねばならず厳密な 解析を行なうことははなはだ困難である。理論的には かなり大きな仮定を設けなければならない。

熱交換器の流量変化比する温度応答に関する従来 の研究はあまり多くなく，しかもその大部分は一方の

* 日本機械学会で発表 (昭 $41 \cdot 4 \cdot 1)$
流体の温度が一定で, 解析が容易な場合に限られてい る いることによって, 応答の最終值がかなり異なってく るが，この点の吟味があまり行なわれていないよらで ある3

熱収支, 保温方法などの一般に非定常特性関して はあまり考慮されない要素をらくめて, 静的な特性と 構造定数とより非定常特性を推定することは，実体設 計にあたって非定常特性を吟味しらるための試みとし て意義あるものと考光る。また，この静的な特性は実 体的研究・実践の歴史的蓄積によって, 構造上の実体 的諸元より定量的に算出することは十分可能である.

このような見地にたって，まずシェル・アンド・チ ューブ式の熱交換器による流体の相変化をともなわな い熱交換プロセスを対象に実験研究を始めた。シェル ・アンド・チューブ式の熱交換器ではバッフル・プレ 一トの効果のように厳密な解析を行ないがたい素因を ともなら．本報告では，石油工業などでェア・クーラ として多く用いられているよらな条件一一流体が液と 気体の場合一について, 非定常特性をできるかぎり 
簡単な形で推定することを試みた。そこでは，実験上 の便宜を考慮して，ステップ状入力に対する応答（ス テップ応答）を用いて，非定常特性を評価した。いま だ検討すべき点もあるが一応の成果を光たのでここに 抄報する。

\section{2. 実験装置の概要}

実験装置の概略図をFig. 1 亿示す。実験に用いた 熱交換器はシェル・アンド・チューブ式で，その仕様 要目を Table 1 亿示与. 供試熱交換器は, ハイ・フ インチューブを用いた熱交換器 I と,フィンのないべ アチューブを用いた熱交換器 II である.

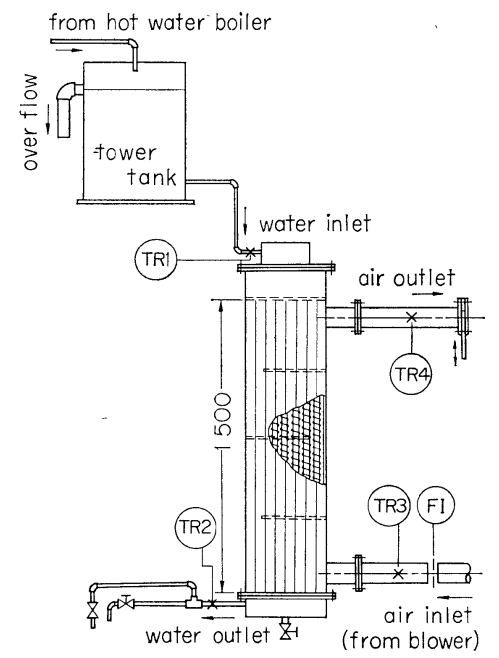

Fig. 1 Flow sheet

\begin{tabular}{c|c|c}
\hline & heat-exchanger I & heat-exchanger II \\
\hline type & shell \& tube type & sell \& tube type \\
\hline tubes & fin-tube(copper) & $\begin{array}{c}\text { bare-tube } \\
\text { (copper) }\end{array}$ \\
$\begin{array}{c}\text { inside dia. of the } \\
\text { tube } \\
\text { outside dia. of the } \\
\text { tube } \\
\text { number of the } \\
\text { tubes }\end{array}$ & $\begin{array}{c}39.7 \mathrm{~mm} \text { (max. } \\
\text { dia. of fin) }\end{array}$ & $16 \mathrm{~mm}$ \\
$\begin{array}{c}\text { area of heat } \\
\text { transfer surface } \\
\text { (out side) }\end{array}$ & 38 & $52 \mathrm{~m}^{2}$ \\
\hline
\end{tabular}

Table 1 Specificaon of the heat exchangers

高温側流体は温水で, 温水ボイラからつねにオーハ フローする定水位高架水槽へいったんたくわえられた のちに, 熱交換器へ送られる. 低温側流体は空気で, ブロワから供給される. 温水流量は熱交換器出口に設 けられたバルブによって調節される。亦さ空気流量は 熱交換器出口のスライド・ダンパによって調節され， 大気に解放される。保温を考慮してへッダ部には保温
材を用い、シェルのまわりにはビニール・シートを用 いて外気としゃ断している.

熱交換器の出・入口に抢ける温度は, 保護管外径 1 $\mathrm{mm}$ の銅・コンスタンタン熱電対により検出し，自動 平衡記録計（平衡速度 $1 \mathrm{~s}$ ）に指示・記録させる．温 水流量は重量法にて計測し, 空気流量は直管部に設け たオリフィスにより計測している。

\section{3. 静特性について}

まず熱交換器の静的な特性の評価項目として熱通過 率，放熱特性の実験結果について述べよう。

\section{〔熱通過率〕}

流量変化によって直接変化するのは熱伝達率である が，実際に熱交換器を使用する立場からは熱通過率に 注目するのが一般的であるう。

実駼結果から熱通過率を求めるにあたり，

（1）温度差として対数平均温度差を用いる。

（2）温水が熱交換器内で失なら熱量は，いったん 空気へ伝兄られ，空気側からシェルを介して放 熱が行なわれるものとする。

（3）伝熱面積として外表面積を用いる. ことにする。このとき熱通過率 $K$ はづのようになる。 $K=\frac{G_{W s} c_{p W}\left(\theta_{i s}-\theta_{0 s}\right)}{A \Delta \theta_{m}}\left[\mathrm{kcal} / \mathrm{m}^{2} \cdot \mathrm{h} \cdot \mathrm{deg}\right]$

ここに, $K:$ 熱通過率 $\left[\mathrm{kcal} / \mathrm{m}^{2} \cdot \mathrm{h} \cdot \mathrm{deg}\right]$

$G:$ 重量流量 $[\mathrm{kg} / \mathrm{h}]$

$c_{p}:$ 定圧比熱 $[\mathrm{kcal} / \mathrm{kg} \cdot \mathrm{deg}]$

$A:$ 伝熱面積（外表面積基準） $\left[\mathrm{m}^{2}\right]$

$\Delta \theta_{m}:$ 対数平均温度差 $[\mathrm{deg}]$

$\theta:$ 温度 $\left[{ }^{\circ} \mathrm{C}\right]$

添字Wは温水を， $s$ は定常状態を表わす。

上式から求めた熱通過率を, 温水流量を媒変数とし て空気流量との関係で示したものが Fig. 2 である.

(3.1) 式で定義される熱通過率は, 両流体が管に 平行に流れるときのもので, シェル・アンド・チュ 一ブ式の場合は異なるが, 慣用に従っておく”(過渡 特性の項で詳述する)。

熱交換器 I と II とについて比較すると，熱通過率は 熱交換器 II の注うが約 3 倍大きい，これは伝熱面積を 外表面積基準にとったためである (Table 1 参照).

Fig. 2 から, 熱通過率は温水流量によっては注と んど変化せず，空気流量によって大きく変化すること がわかる，すなわち，空気流量変化に対する過渡特性 を検討するさいには，熱通過率の変化を考慮しなけれ ばならない。

〔放熱特性】 


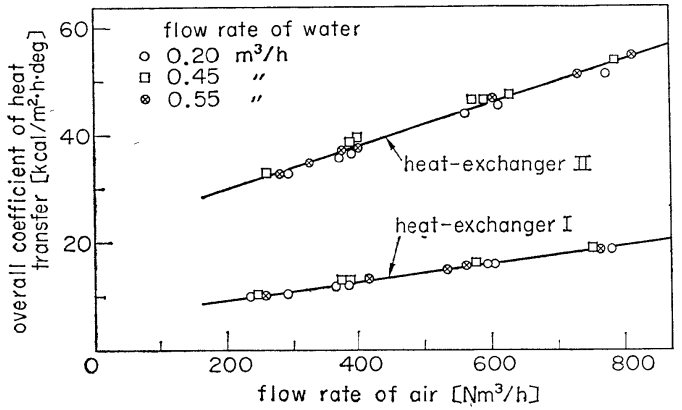

Fig. 2 Overall coefficient of heat transfer

温水が熱交換器内で失なら熱量と, 空気が熱交換器 内でえる熱量との差を放熱とみなすことができる。 こ の放熱は，空気側からシェルを介して行なわれると考 兄られるので, シェル内空気の平均温度（熱交換器出 -入口に批る空気温度の相加平均）と外気温度との 温度差によって，放熱量を整理すると Fig. 3 のよう になる．放熱量沉ついて熱交換器 I と II とを比較して みるとかなり異なっている. 実験時の気像条件の相異, 設置場所の相異などによるものと思われるが，本旨で はないので比較・検討は割愛する。

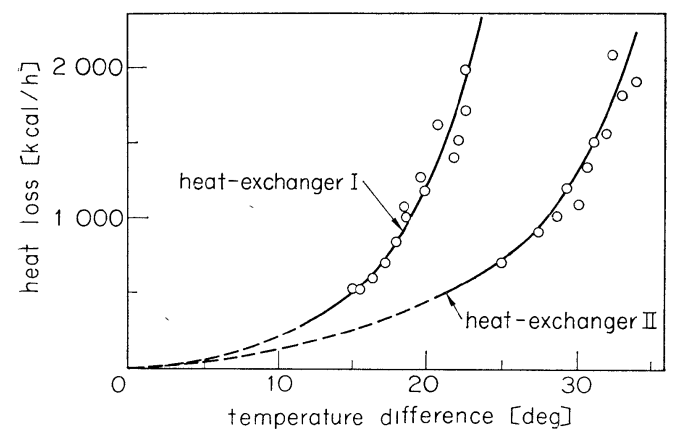

Fig. 3 Heat loss

\section{4. ステップ応答実験}

熱交換器り過渡特性を定量的に実験で求める方法と 乙ては, 過渡応答法 (ステップ応答), 周波数応答法, ランダム信号の利用，ハルス応答法などがあるが，こ こでは温水流量あるいは空気流量のステップ状変化に 対する熱交換器出口の温水温度拉よび空気温度の応答 に注目する過渡応答法によることにした。

\section{〔空気流量変化に対するステップ応答実験〕}

温水入口温度以約 $85^{\circ} \mathrm{C}$ 一定と. ᄂ, 温水流量 0.6 , $0.4,0.2 \mathrm{~m}^{3} / \mathrm{h}$ について, 空気流量を $200 \sim 800 \mathrm{Nm}^{3} / \mathrm{h}$ の範用で，振幅を約 $200 \mathrm{Nm}^{3} / \mathrm{h}$ にとってステップ状 変化させた。操作は空気出口側のスライド・ダンパ で行ない，熱交換器出口温度の㐫答は前述の自動平衡
記録計（チャート送り速度 $25 \mathrm{~mm} / \mathrm{min}$ ) によって記 録した。

このステップ応答の様相について, 熱交換器 I と II とを比較してみるときわめて類似している。ここでは， とくに熱交換器 IIの例を示すことにする。実験結果を Fig. $4($ a) (b) 飞例示与る. 応答の様相は温水流量汇 よって著しく異なるが，空気流量を增加したときと減 少したときとではほとんど変化しない，

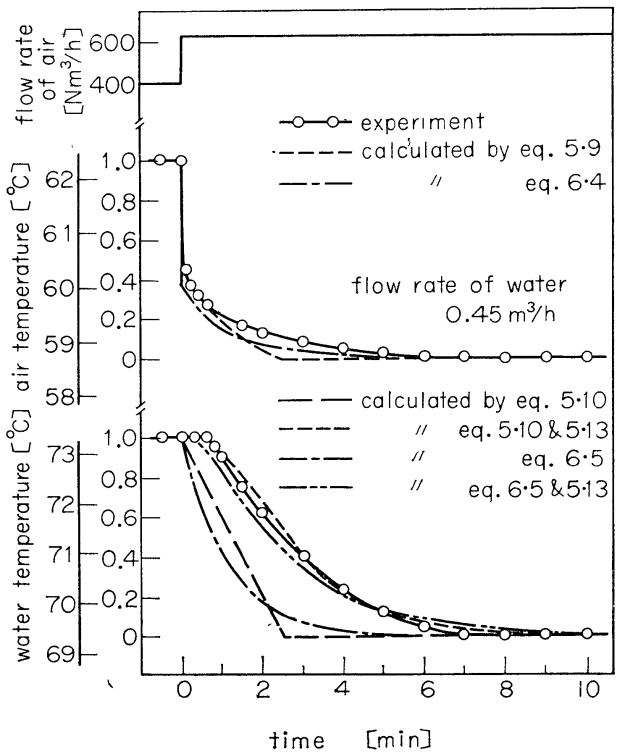

(a)

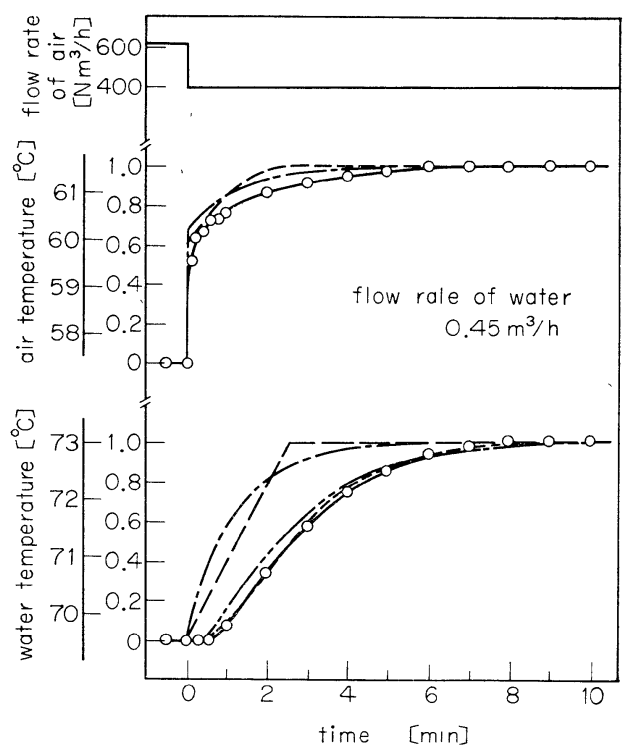

(b)

Fig. 4 Step response (air flow rate change) 


\section{〔温水流量変化に対するステップ応答実験】}

空気流量 $800,400 \mathrm{Nm}^{3} / \mathrm{h}$ について, 温水流量を $0.2 \sim 0.6 \mathrm{~m}^{3} / \mathrm{h}$ の簳囲で, 振幅を約 $0.1 \mathrm{~m}^{3} / \mathrm{h}$ にとっ てステップ状に変化させた。操作は熱交換器出口に設 けたコックを切り換えることによって行なった．実験 結果を Fig 5 (a) (b) 飞例示する. 応答の様相は, 温 水流量の增加時と減少時とでは著しく異なる.

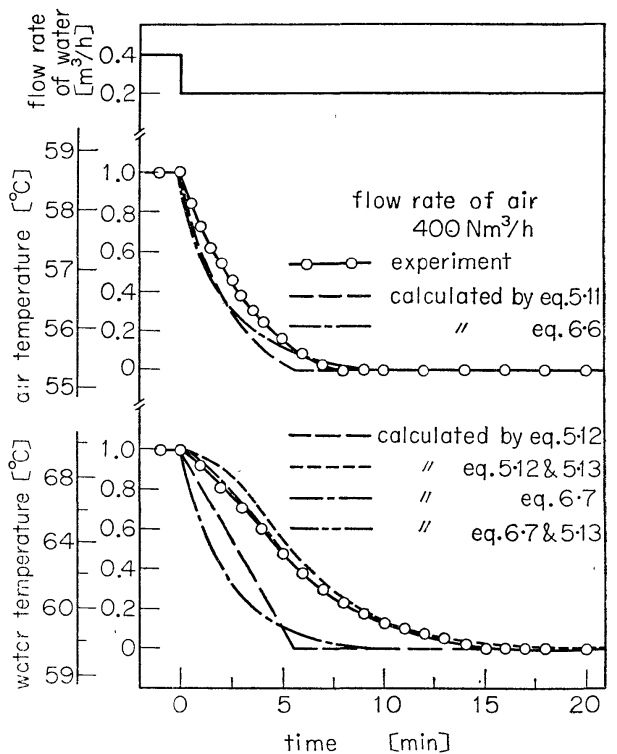

(a)

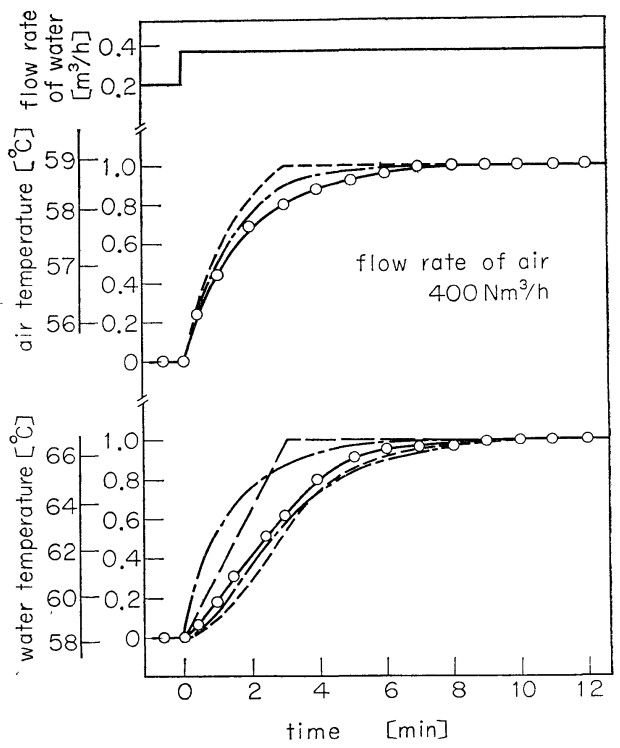

(b)

Fig. 5 Step response (water flow rate change)

\section{5. 流量変化に対する応答の推定 $(1)$}

従来の流量変化に対する熱交換器の過渡特性に関す る解析は, 図式解法4), 線形化による解法などによっ て行なわれているが，熱交換器の制御問題汇適用する にあたっては，問題点が少なくない。すなわち，流量 変化による熱通過率の変化を考慮したものが少ないこ と,さらに線形化によって生ずる䛊差(とくに最終值) についての吟味が従来欠けているようである。また， 図式解法に上る解，あるいは数值解はその李制御問 題に適要しにくいなどの難点をもつ。ここでは，熱交 換器の構造定数さらに静的な特性值から過渡特性を推 定する方法に重点を扣き，熱交換器の制御について検 討するときに利用できるように配慮する。

\section{[基礎方程式]}

供試熱交換器の構造は, Fig. 1 亿示すようにシェ ル・アンド・チューブ式で 3 枚のバッフル・プレート が設けられている。装置工業において実際に使用され ているシェル・アンド・チューブ式熱交換器に揖いて す, バッフル・プレートが必ず用いられている。この ような対象について，単密解析を行なうことはきわ めて困難である，そこでモデル化を行なって流量変化 に対する応答の推定を試みる。モデルとしては，管内 流体については分布定数系として扱い，シェル側流体 については集中定数系として报らモデルを考学る (Fig. 6).

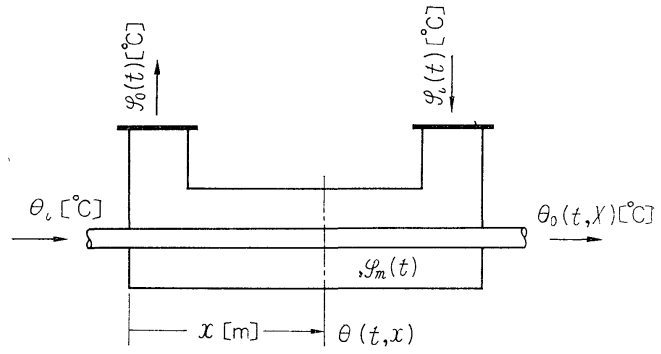

Fig. 6 Modelling of the heat-exchanger

シェル側流体として気体が用いられるときには， 気体のシェル内滞留時間は管内流体の滞留時間に比 して十分短いことが多い。供試熱交換器の場合, 温 水の管内滞留時間 $2 \sim 6 \mathrm{~min}$ ，空気のシェル内滞留 時間 $0.2 \sim 0.8 \mathrm{~s}$ である. したがって，このモデル はかなりこのシチュエーションに適正なるのであ る.

このモデルに拈ける基礎式はつぎのようになる。

$$
\begin{aligned}
& \left(w_{T}+w_{W}\right) \frac{\partial \theta}{\partial t}+v_{W} w_{W} \frac{\partial \theta}{\partial x} \\
& \quad=K U\left(\varphi_{m}-\theta\right)[\mathrm{kcal} / \mathrm{m} \cdot \mathrm{h}]
\end{aligned}
$$




$$
\begin{aligned}
w_{A} \frac{\partial \varphi_{m}}{\partial t} & =\int_{0}^{x} K U\left(\theta-\varphi_{m}\right) d x \\
& -2 w_{A} v_{A}\left(\varphi_{m}-\varphi_{i}\right)-Q_{\mathrm{LOSS}}[\mathrm{kcal} / \mathrm{h}]
\end{aligned}
$$

ここに, $w$ : 単位長さあたりの熱容量 $[\mathrm{kcal} / \mathrm{m} \cdot \mathrm{deg}]$

$v:$ 流速 $[\mathrm{m} / \mathrm{h}]$

$U:$ 単位長さあたりの伝熱面積 $\left[\mathrm{m}^{2} / \mathrm{m}\right]$

$K:$ 熱通過率 $\left[\mathrm{kcal} / \mathrm{m}^{2} \cdot \mathrm{h} \cdot \mathrm{deg}\right]$

$\theta:$ 管内流体 (温水) の温度 $\left[{ }^{\circ} \mathrm{C}\right]$

$\varphi:$ シェル側流体 (空気) の温度 $\left[{ }^{\circ} \mathrm{C}\right]$

$\varphi_{m}:\left(\varphi_{i}+\varphi_{o}\right) / 2\left[{ }^{\circ} \mathrm{C}\right]$

$Q_{\text {LOSS }}$ : 放熱量 $[\mathrm{kcal} / \mathrm{h}]$

$x$ : 管の長手方向への距離 $[\mathrm{m}]$

添字 $W 、 A$ はそれぞれ温水，空気，また添

字 $i, o$ は熱交換器入口，出口を表わす.

上述の基礎式を導くにあたり，一般に用いられてい る仮定の活かにつぎのような仮定を用いた。

[仮 1]シェル内空気の温度は, 入口, 出口温度の相 加平均とする.

〔仮 2】温水通路は総管内断面積に等しい断面積をも つ単一管とみなす（各管内は一样に流れてい るものとする).

〔仮 3 〕熱通過率は管長にそって一定とする。

〔仮 4]管の熱容量は温水に付加して考慮する.管内 の熱抵抗は管外の熱抵抗よりも小さいので, この仮定を導入した。

〔仮 5】シェルと保温材の熱容量は無視する。また流 量変化による放熱量の変化は小さいので放熱 量は一定とする。

この仮定の吟味は後述する。

〔仮 6〕空気流量变化の場合, 空気流量子同時飞熱通 過率は変化するものとする．末た温水流量変 化の場合は，熱通過率は変わらないものとす る(Fig. 2 を参照).

シェル側流体が気体の場合にはそのシェル内の熱容 量は十分小さいのでこれを無視すれば，基礎式はつぎ のようになる。

$$
\begin{gathered}
\left(w_{T}+w_{W}\right) \frac{\partial \theta}{\partial t}+v_{W} w_{W} \frac{\partial \theta}{\partial x} \\
=K U\left(\varphi_{m}-\theta\right)[\mathrm{kcal} / \mathrm{m} \cdot \mathrm{h}] \\
K U \int_{0}^{X}\left(\theta-\varphi_{m}\right) d x \\
=2 w_{A} v_{A}\left(\varphi_{m}-\varphi_{i}\right)+Q_{\mathrm{LOSS}}[\mathrm{kcal} / \mathrm{h}]
\end{gathered}
$$

供試熱交換器の例では, シェル内空気の熱容量忹 $0.02 \mathrm{kcal} / \mathrm{deg}$ である.

【定常解]
基礎式に和いて， $\partial / \partial t=0$ と利くことによって定常 解をえることができる。

$$
\theta_{s}(x)=\varphi_{m s}+\left(\theta_{i s}-\varphi_{m s}\right) \exp \left(-\frac{K_{s} U x}{v_{W s} w_{W}}\right)\left[{ }^{\circ} \mathrm{C}\right]
$$

よって熱通過率は (5.6) 式のようになる.供試熱交換 器に括いては，(3.1) 式によって定義される熱通過率 は（5・6）式によるものとほとえぞ同じ值であった。

$$
K_{s}=\frac{v_{W} w_{W}}{U X} \ln \left(\frac{\theta_{i s}-\varphi_{m s}}{\theta_{o s}-\varphi_{m s}}\right)\left[\mathrm{kcal} / \mathrm{m}^{2} \cdot \mathrm{h} \cdot \mathrm{deg}\right]
$$

\section{[空気流量変化に対するステップ応答】}

いま空気流量がステップ状に変化して，空気のシェ 儿内流速が $v_{A S} \mathrm{~m} / \mathrm{h}$ から $\Delta v_{A}$ だけ変化したとする. このとき, 熱交換器出口温度がそれぞれ $\theta, \varphi_{m}{ }^{\circ} \mathrm{C}$ か ら $\Delta \theta, \Delta \varphi_{m}$ 変化したとすれば， $(5 \cdot 1 ， 2)$ 式は (5. $7 ， 8)$ 式のよう记書き直すことができる（空気流量変 化の場合は熱通過率の变化を考慮しなけ玌ばならな い).

$$
\begin{aligned}
W \frac{\partial}{\partial t}(\Delta \theta) & +v_{W} w_{W} \frac{\partial}{\partial x}(\Delta \theta) \\
= & K U\left(\Delta \varphi_{m}-\Delta \theta\right)+\Delta K U\left(\varphi_{m s}-\theta_{s}\right)
\end{aligned}
$$

$$
\begin{array}{r}
K U \int_{0}^{X}\left(\Delta \theta-\Delta \varphi_{m}\right) d x+\Delta K U \int_{0}^{x}\left(\theta_{s}-\varphi_{m s}\right) d x \\
=2 v_{A} w_{A} \Delta \varphi_{m}+2 \Delta v_{A} w_{A}\left(\varphi_{m s}-\varphi_{i}\right)
\end{array}
$$

ここに，山は定常状態からの变化分を表わす。また

$$
\begin{aligned}
& W \equiv w_{T}+w_{W}, \\
& K \equiv K_{s}+\Delta K \text { である. }
\end{aligned}
$$

ラプラス変換を用いて $(5 \cdot 7,8)$ 式から温水出口温 度变化 $\Delta \Theta(s, X)$, 空気出口温度变化 $\Delta \Phi_{m}(s)$ を求め ると,つぎのようになる。

$\Delta \Phi_{m}(s)$

$=\frac{(1+s W / K U)\left[b_{2} s^{2}+b_{1} s+b_{0}+b_{L} \exp \{-F(s) X\}\right]}{s(1+s W / \Delta K U)\left[a_{2} s^{2}+a_{1} s+a_{0}+a_{L} \exp \{-F(s) X\}\right]}$

$$
\begin{aligned}
\text { ここに, } \\
a_{L} \equiv-v_{W} w_{W}, \\
a_{0} \equiv v_{W} w_{W}+2 v_{A} w_{A}, \\
a_{1} \equiv(W / K U)\left(4 v_{A} w_{A}+K U X\right), \\
a_{2} \equiv(W / K U)^{2}\left(2 v_{A} w_{A}+K U X\right), \\
b_{l} \equiv-v_{W} w_{W}\left(\theta_{i s}-\varphi_{m s}\right), \\
b_{0} \equiv v_{W} w_{W}\left(\theta_{o s}-\varphi_{m s}\right)-2 \Delta v_{A} w_{A}\left(\varphi_{m s}-\varphi_{i}\right), \\
b_{1} \equiv\left(\frac{W}{K U}\right)\left\{\Delta K U\left(\frac{v_{W} w_{W}}{K_{s} U}\right)\left(\theta_{2 s}-\theta_{o s}\right)\right. \\
\left.-2 \Delta v_{A} w_{A}\left(1+\frac{K}{\Delta K}\right)\left(\varphi_{m s}-\varphi_{i}\right)\right\},
\end{aligned}
$$




$$
\begin{aligned}
& b_{2} \equiv\left(\frac{W}{K U}\right)\left(\frac{W}{\Delta K U}\right)\left\{\Delta K U\left(\frac{v_{W} w_{W}}{K_{s} l^{r}}\right)\left(\theta_{\imath s}-\theta_{o s}\right)\right. \\
& \left.\quad-2 \Delta v_{A} w_{A}\left(\varphi_{m s}-\varphi_{i}\right)\right\}, \\
& F(s) \equiv(K U+s W) /\left(v_{W} w_{W}\right) \\
& \Delta \Theta(s, X) \\
& =\frac{b_{2} s^{2}+b_{1} s+b_{0}-b_{L} \exp \{-F(s) X\}}{s(1+s W / \Delta K U)\left[a_{2} s^{2}+a_{1} s+a_{0}+a_{L} \exp \{-F(s) X\}\right]} \\
& +\frac{\theta_{s}-\varphi_{m s}}{s(1+s W / \Delta K U)}\left[\exp \left(-\frac{K_{S} U}{v_{W} w_{W}} X\right)\right. \\
& -\exp \{-F(s) X\}]
\end{aligned}
$$

$(5 \cdot 9,10)$ 式から $t$ 領域に书ける応答を求めること ができる。しかし，みかけ上の滞留時間までの $t$ 領域 に怙ける応答は容易に求めることができるが，それ以 後の応答を厳密に求めることは困難である。

温水の管内滞留時間は $\left(X / v_{W}\right) \mathrm{h}$ であるが，管の 熱容量を温水に付加したことによってみかけ上の滞 留時間はつぎのように長くなる。

滞留時間 $=\left(1+\frac{w_{T}}{w_{W}}\right)\left(\frac{X}{v_{W}}\right)[\mathrm{h}]$
しか乙，制御問題に適用するさいには応答の初期に より多く注目すべきこと, またみかけ上の滞留時間経 過時には応答がかなり取束していることより，みかけ 上の滞留時間までの $t$ 領域に拈ける応答式で十分実用 に供しえるものと考えられる。

供試熱交換器の場合には, みかけ上の滞留時間経過 時の応答と，応答の最終值との差が，2\%以内に市さ まることが数值計算により確認されたので, みかけ上 の滞留時間で応答は整定するものとみなす。

そこで，(5.9，10) 式に数值を代入して逆ラプラス 変換を行なって求めた理論応答曲線を，Fig. 4 の実 験結果に破線で併記する。

\section{[温水流量変化に対するステップ応答〕}

温水流量変化の場合には，熱通過率は一定とみなす ことができる.いま温水流量がステップ状に変化して， 温水の管内流速が $v_{W S} \mathrm{~m} / \mathrm{h}$ から $\Delta v_{W}$ だけ変化したと すれば，熱交換器出口に括ける空気温度変化および温 水温度変化は $s$ 領域でつぎのよらになる。

$$
\begin{aligned}
& \Delta \Phi_{m}(s)=\frac{(1+s W / K U)\left[C_{1} s+C_{0}+C_{L} \exp \{-F(s) X\}\right]}{s\left\{(W / K U)\left(u_{W s} / \Delta V_{W}\right) s-1\right\}\left[a_{2} s^{2}+a_{1} s+a_{0}+a_{L} \exp \{-F(s) \cdot X\}\right]} \\
& \text { ここに, } \quad C_{L} \equiv v_{W} w_{W}\left(\theta_{i s}-\varphi_{m s}\right) \\
& C_{0} \equiv-v_{W s} w_{W}\left(\theta_{o s}-\varphi_{m s}\right)-\Delta v_{W} w_{W}\left(\theta_{i s}-\varphi_{m s}\right) \\
& C_{1} \equiv(W / K U)\left\{v_{W s} w_{W}\left(\theta_{2 s}-\theta_{o s}\right)\right\} \\
& \Delta \Theta(s, X)=\frac{C_{1} s+C_{0}+C_{L} \exp \{-F(s) \cdot X\}}{s\left\{(W / K U)\left(v_{W s} / \Delta v_{s}\right) s-1\right\}\left[a_{2} s^{2}+a_{1} s+a_{0}+a_{L} \exp \{-F(s) X\}\right]} \\
&-\frac{\theta_{2 s}-\varphi_{m s}}{s(W / K U)\left\{(W / K U)\left(v_{W} / \Delta v_{W}\right) s-1\right\}}\left[\exp \left\{-\left(\frac{K U}{v_{W s} w_{W}}\right) X\right\}-\exp \{-F(s) X\}\right]
\end{aligned}
$$

前述の場合と同様にして，みかけ上の滞留時間経過 時屯での応答を容易に求めることができる. 数值を代 入して逆ラプラス変換を行なって求めた理論応答曲線 を, Fig. 5 の実験結果に破線で併記する.

\section{〔温水出口側ヘッダ部の考慮〕}

シェル・アンド・チューブ式熱交換器の構造上, 温 水出口側ヘッダ部は必ず付属している。いままでの空 気流量変化, 温水流量変化に対与る温水出口温度の応 答の計算に拈いては, 温水出口側へッダ部によるおく れの影響は考慮されていない. Fig. 1 に示すよらに熱 交換器の構造からこの出口側へッダ部内に和いて, か なり混合が行なわれていると推測される，そこで完全 混合による一次沶くれとみなすことにすると，実際の 熱交換器出口にお汗る温水温度の理論応答は,

$$
\Theta_{E}(s)=\frac{1}{1+s T_{E}} \Theta(s, X)
$$

ここに, $T_{E}$ は温水出口側へッダ部の温水の滞留時 間である。
(5.13) 式による温水出口温度の理論応答曲線を,

Fig. 4, 5 の実験結果に点線で併記する.

温水入口側ヘッダ部内の温水は均温とみなすこと ができるので，その影響は流量変化のさいは考学る 必要はない。

制御の立場からシェル・アンド・チューブ式熱交換 器の構造をみるときには, この温水出口側へッダ部に 注意しなければならない。

\section{[実験結果との比較・検討]}

実験によってえられた応答曲線と理論応答曲線とを 比較してみよう。このさい，温水出口温度については 温水出口側ヘッダ部を考慮した応答曲線について比較 を行ならべきである。

空気流量変化に対する温水出口温度の応答には，か なりよい近似がえられている。また空気出口温度の応 答は，応答の初期に注目すればよい近，似がえられてい る.しかし計算值のほらが実験值よりも収束がはやい. これはシェルと保温材の熱容量などによるものと思わ 
れるが，この点については後述する。

温水流量変化に対する応答についても, 計算值の汪 らが実験值よりもはやく収束する。

\section{[周波数領域における検討]}

$s$ 領域に和ける応答式から $t$ 領域における理論応答 曲線を求めるにあたって, 応答がみかけ上の滞留時間 経過で注晸定することに注目して，(5.9，10) 式に
フ抌いて $\exp \left[-\left\{(K U+s W) /\left(v_{W} w_{W}\right)\right\} X\right]$ の項を省略 した。この省略の妥当性について, 周波数領域で検討 する．ここでは空気出「温度の応答についての例を示 于.

(5.9) 式で $\exp \left[-\left\{(K U+s W) /\left(v_{W} w_{W}\right)\right\} X\right]$ の項 を省略してみかけ上の滞留時間で応答が整定するもの とすれば，応答式は， $s$ 領域でつぎのよらになる。

$$
\Delta \Phi_{m}(s)= \begin{cases}\frac{(1+s W / K U)\left(b_{2} s^{2}+b_{1} s+b_{0}\right)}{s(1+s W / \Delta K U)\left(a_{2} s^{2}+a_{1} s+a_{0}\right)} & 0 \leq t \leq \frac{W X}{v_{W} w_{W}} \\ \Delta \varphi_{m}\left(W X / v_{W} w_{W}\right) / s & t>\frac{W X}{v_{W} w_{W}} .\end{cases}
$$

(5.9) 式による周波数特性を実線で，(5.14) 式に よる周波数特性を破線で Fig. 7 に示す.な打 1 点鎖 線で集中・集中定数系による計算式 (6.4) 式による 周波数特性を併記する.

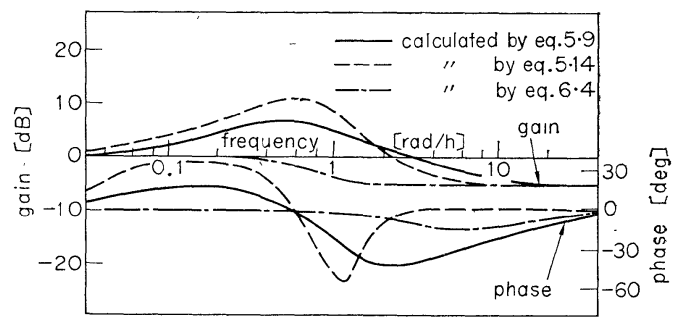

Fig 7 Consideration in the frequency domain な和，1/s の項を除いて周波数特性を求めた.

この結果から明らかなよらに，(5.9，10) 式に扣い $\tau \exp \left[-\left\{(K U+s W) /\left(v_{W} w_{W}\right)\right\} X\right]$ の項を省略して も大きな差異がない。

Fig. 7 は単なる周波数領域に抢ける比較である. 流量を正弦波状に変化させたときの周波数特性とは異 なる。

\section{6. 流量変化に対する応答の推定 (2)}

応答の推定（1）では分布・集中定数系のモデルとオ
オして取り扱った。つぎ管内温水およびシェル内空気 ともに集中定数系として取り扱抢う.

管内温水温度は入口と出口の相加平均と仮定する. その他の仮定は，前に用いたものを準用するものとす る.

\section{[基礎式]}

$$
\begin{array}{r}
C_{W}\left(d \theta_{m} / d t\right)=2 v_{W} w_{W}\left(\theta_{\imath}-\theta_{m}\right) \\
-\beta\left(\theta_{m}-\varphi_{m}\right)[\mathrm{kcal} / \mathrm{h}] \\
2 v_{W} w_{W}\left(\varphi_{m}-\varphi_{i}\right)=\beta\left(\theta_{m}-\varphi_{m}\right) \\
-Q_{\text {Loss }}[\mathrm{kcal} / \mathrm{h}]
\end{array}
$$

乙こに， $\beta$ は相当熱コンダクタンス $[\mathrm{kcal} / \mathrm{h} \cdot \mathrm{deg}]$ であり, 次式により定義される（定常解から容易に求 まるが前に求めた Kとほぼ同じ值である).

$$
\beta=\frac{2 v_{W} w_{W}\left(\theta_{i}-\theta_{m s}\right)}{\theta_{m s}-\varphi_{m s}}[\mathrm{kcal} / \mathrm{h} \cdot \mathrm{deg}]
$$

また， $C_{W}$ : 管内温水と管との熱容量 $[\mathrm{kcal} / \mathrm{deg}]$.

\section{[空気流量変化に対するステップ応答]}

空気流量がステップ状に変化して, 空気のシェル内 流速が $v_{A s} \mathrm{~m} / \mathrm{h}$ から $\Delta v_{A}$ だけ，末た相当熱コンダ クタンスが $\beta_{S}$ から $\Delta \beta$ だけ変化したとすれば，熱交 換器出口に拈ける空気温度変化括よび温水温度変化は それぞれつぎのようになる。

$$
\begin{array}{cc} 
& \Delta \Phi_{m}(s)=\frac{C A s+2 v_{W} w_{W} \Delta \beta\left(\theta_{m s}-\varphi_{m s}\right)-2 \Delta v_{A} w_{A}\left(2 v_{W} w_{W}+\beta\right)\left(\varphi_{m s}-\varphi_{\imath}\right)}{s\left\{C\left(2 v_{A} w_{A}+\beta\right) s+2 v_{W} w_{W}\left(2 v_{A} w_{A}+\beta\right)+2 v_{A} w_{A} \beta\right\}} \\
\text { ここに, } \quad A \equiv \Delta \beta\left(\theta_{m s}-\varphi_{m s}\right)-2 \Delta v_{A} w_{A}\left(\varphi_{m s}-\varphi_{i}\right) . \\
\Delta \Theta(s)=\frac{-2 v_{A} w_{A} \Delta \beta\left(\theta_{m s}-\varphi_{m s}\right)-2 \Delta v_{A} w_{A} \beta\left(\varphi_{m s}-\varphi_{1}\right)}{s\left\{C\left(2 v_{A} w_{A}+\beta\right) s+2 v_{W} w_{W}\left(2 v_{A} w_{A}+\beta\right)+2 v_{A} w_{A} \beta\right\}}
\end{array}
$$

上式に逆ラプラス変換を行なって, $t$ 領域に和ける 応答を求めることができる. 数值を代入して求めた結 果を, Fig. 4 の実験結果に 1 点鎖線で併記する。な 况温水出口温度については, 温水出口側のヘッダ部の 影響を考慮したものを2 点鎖線で示す。

\section{入[温水流量変化に対するステップ応答]}

相当熱コンダクタンス $\beta$ を一定とみなすことができ るので, 空気流量変化の場合よりも簡単に出口温度の 応答を求めることができる。

$$
\begin{aligned}
& \Delta \Phi_{m}(s)=\frac{\beta\left\{2 \Delta v_{W} w_{W}\left(2 v_{A} w_{A}+\beta\right)\left(\theta_{i s}-{ }_{m s}\right)\right\}}{s\left(2 v_{A} w_{A}+\beta\right)\left\{s C\left(2 v_{A} w_{A}+\beta\right)+4 v_{W} w_{W} v_{A} w_{A}+2 \beta\left(v_{A} w_{A}+v_{W} w_{W}\right)\right\}} \\
& \Delta \Theta(s)=\frac{2 \Delta v_{W} w_{W}\left(2 v_{A} w_{A}+\beta\right)\left(\theta_{i}-\theta_{m s}\right)}{s\left\{s C\left(2 v_{A} w_{A}+\beta\right)+4 v_{W} w_{W} v_{A} w_{A}+2 \beta\left(v_{A} w_{A}+v_{W} w_{W}\right)\right\}}
\end{aligned}
$$


数值を代入乙て $t$ 領域に和壮る応答を求めた結果を, Fig. 5 に 1 点鎖線で併記する. また温水出口側へッ ダ部の影響を考慮した温水出口温度の理論応答曲線を 2 点鎖線で示す.

\section{[比較・検討]}

実験で求めた応答と，集中・集中定数系として推定 した理論応答曲線とを比較してみると, 集中定数系と してのェデルにもかかわらず，かなりよい近似がえら えている.

分布・集中定数系のモデルによる理論応答曲線のほ らが，集中・集中定数系のモデルによるものよりも； 応答の初期にはよい近似が党られる。 しかし両者とも に実際の応答よりも収束がはやい（とくに温水流量変 化のときにこの傾向は著しい）。

\section{7．シェルと保温材の熱容量による影響}

いままでの理論応答曲線の推定にあたっては, シェ ルと保温材の熱容量を無視してきた。このために理論 応答曲線は実験結果よりも収束するのがはやいものと 推測される.ここで, シェルと保温材の熱容量を考慮 し, さらに放熱量は動作点近傍で接線近似を行なって (Fig. 3) シェル内空気の平均温度と外気との温度差 に比例するものとして, 流量変化に対する過渡特性に ついて検討してみよう。

供試熱交換器に拈いては，シェルのまわりにビニ ールシートを用いて外気と空気をしゃ断しているだ
けなので，保温材の熱容量はシェルに比して十分無 視できる。

[分布・集中定数系としてのモデル]

シェルの各部に拈ける温度は一様であるとして（シ エル部分を集中定数系として）基礎式をたてると，つ ぎのようになる。

$$
W(\partial \theta / \partial t)+v_{W} w_{W}(\partial \theta / \partial x)=K U\left(\varphi_{m}-\theta\right)
$$

$$
\begin{aligned}
& \int_{0}^{X} K U\left(\theta-\varphi_{m}\right) d x=2 v_{A} w_{A}\left(\varphi_{m}-\varphi_{\imath}\right)+\alpha_{s}\left(\varphi_{m}-\psi\right) \\
& C_{\text {Shell }}(d \psi / d t)=\alpha_{s}\left(\varphi_{m}-\psi\right)-\alpha_{L}\left(\psi-\psi_{0}\right) \cdots \cdots(7 \cdot 3) \\
& \text { ここに， } \alpha_{s} \text { : シェル側空気からシェルベの熱コン } \\
& \text { ダクタンス }(\div 40)[\mathrm{kcal} / \mathrm{h} \cdot \mathrm{deg}] \\
& \alpha_{L}: \text { シェルから外気への熱コンダクタン } \\
& \text { ス }[\mathrm{kcal} / \mathrm{h} \cdot \mathrm{deg}] \\
& C_{\text {Shell }} \text { : シェルの熱容量 }(\doteqdot 6.0)[\mathrm{kcal} / \mathrm{deg}] \\
& \psi: \text { シェルの温度 }\left[{ }^{\circ} \mathrm{C}\right] \\
& \psi_{0}: \text { 外気温度 }\left[{ }^{\circ} \mathrm{C}\right]
\end{aligned}
$$

紙面の都合で, 空気流量変化に対するステップ応答 を例にとる。いま空気流量がステップ状に変化してシ ェル内空気の流速が $v_{W s} \mathrm{~m} / \mathrm{h}$ から $\Delta v_{W}$ だけ変化 したときに，諸量が $\theta=\theta_{s}+\Delta \theta ， \varphi_{m}=\varphi_{m s}+\Delta \varphi_{m}, K$ $=K_{s}+\Delta K$ と変化したとする。 $\psi \psi$ を消去して, 空気出 口温度および温水出口温度の变化を $s$ 領域で求めると 次式のようになる。

$$
\begin{aligned}
& \Delta \Phi_{m}(s)=\frac{\left(1+s T_{\text {Shell }}\right)(1+s W / K U)\left[b_{2} s^{2}+b_{1} s+b_{0}+b_{L} \exp \{-\{F(s) X\}]\right.}{s T_{\text {Shell }}(1+s W / \Delta K U)\left[d_{3} s^{3}+d_{2} s^{2}+d_{1} s+d_{0}+d_{L}\left(1+s T_{\text {Shell }}\right) \exp \{-F(s) X\}\right]} \\
& \text { ここで, } \quad T_{\text {Shell }} \equiv C_{\text {Shell }} /\left(\alpha_{s}+\alpha_{L}\right) \\
& d_{L} \equiv-v_{W} w_{W}\left\{\left(\alpha_{S}+\alpha_{L}\right) / \mathrm{C}_{\mathrm{Shel1}}\right\} \\
& d_{0} \equiv\left(\frac{\alpha_{S}+\alpha_{L}}{C_{\mathrm{Shell}}}\right)\left(v_{W} w_{W}+2 v_{A} w_{A}+\frac{\alpha_{S} \alpha_{L}}{\alpha_{s}+\alpha_{L}}\right) \\
& d_{1} \equiv\left(v_{W} w_{W}+2 v_{A} w_{A}+\alpha_{s}\right)+\left(\frac{W}{K U}\right)\left(\frac{\alpha_{s}+\alpha_{L}}{C_{\text {Snel1 }}}\right)\left(K U X+4 v_{A} w_{A}+\frac{2 \alpha_{s} \alpha_{L}}{\alpha_{s}+\alpha_{L}}\right) \\
& d_{2} \equiv \frac{W}{K U}\left[\left(K U X+4 v_{A} w_{A}+2 \alpha s\right)+\left(\frac{W}{K U}\right)\left(\frac{1}{C_{\text {Shell }}}\right)\left\{\alpha_{S} \alpha_{L}+\left(\alpha_{s}+\alpha_{L}\right)\left(K U X+2 v_{A} w_{A}\right)\right\}\right] \\
& d_{3} \equiv(W / K U)^{2}\left(K U X+2 v_{A} w_{A}+\alpha_{S}\right) \\
& \Delta \Theta(s, X)=\frac{\left(1+s T_{\text {Shel1 }}\right)\left[b_{2} s^{2}+b_{1} s+b_{0}+b_{L} \exp \{-F(s) X\}\right]}{s T_{\text {Shel1 }}(1+s W / \Delta K U)\left[d_{3} s^{3}+d_{2} s^{2}+d_{1} s+d_{0}+d_{L}\left(1+s T_{\text {Shel1 }}\right) \exp \{-F(s) X\}\right]} \\
& +\frac{\theta_{m s}-\varphi_{m s}}{s(1+s W / \Delta K U)}\left[\exp \left\{-\left(\frac{K_{s} U}{v_{W} w_{W}}\right) X\right\}-\exp \left\{-\left(\frac{K U+s W}{v_{W} w_{W}}-\right) X\right\}\right]
\end{aligned}
$$

$(7 \cdot 4,5)$ 式について逆ラプラス変換を行ならと, 空気流量変化に対する応答が求められる. みか子上の 滞留時間経過時までの応答は容易に求められるが，そ れ以後の応答を計算するのは容易ではない（みかけ上 の滞留時間経過時に応答は整定していない). 述するよらに，集中・集中定数系のモデルでもシェル
フの熱容量を考虑するとかなりよい近似をえることがで きるので，このモデルを用いるのは得策ではない。こ こでは $s$ 領域に抹ける応答式を求めるにとどめる.

\section{[集中・集中定数系としてのモデル]}

このモデルについて, 便宜的に温度アナロジィを用 いて電気回路で表わすと Fig. 8 のようになる。いま 


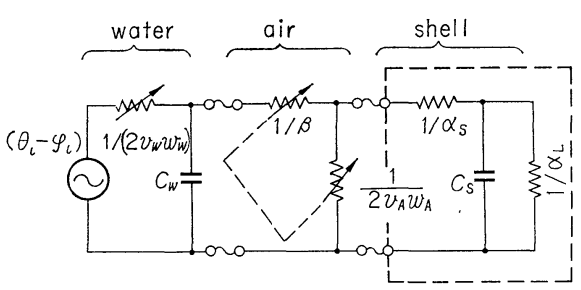

Fig. 8 Temperature analogy

破線で囲まれる部分の影響について検討を行なってい る（流量変化は Fig. 8 に执いて抵抗を変化させるこ とに相当する）.

基礎方程式はシェルの部分についての熱平衡式を考 慮すれば容易に求められる。

$$
\begin{gathered}
\nearrow C_{W}\left(d \theta_{m} / d t\right)=2 v_{W} w_{W}\left(\theta_{i}-\theta_{m}\right)-\beta\left(\theta_{m}-\varphi_{m}\right) \\
2 v_{A} w_{A}\left(\varphi_{m}-\varphi_{i}\right)=\beta\left(\theta_{m}-\varphi_{m}\right)-\alpha_{s}\left(\varphi_{m}-\psi\right) \\
C_{\text {She } 11}(d \psi / d t)=\alpha_{s}\left(\varphi_{m}-\psi\right)-\alpha_{L}\left(\psi-\psi_{0}\right)
\end{gathered}
$$

いま空気流量が变化してシェル内空気流速が $v_{A s}$ から $\Delta v_{A}$ だけ変化したときに， $\beta=\beta_{s}+\Delta \beta, \theta_{m}=$ $\theta_{m s}+\Delta \theta_{m}, \quad \varphi_{m}=\varphi_{m s}+\Delta \varphi_{m}$ と諸量が变化したとする. そのときの, $\Delta \theta_{m}, \Delta \varphi_{m}$ を $s$ 領域で求めるとつぎの ようになる。

$$
\Delta \Phi_{n}(s)=\frac{B_{2} s^{2}+B_{1} s+B_{0}}{s\left(A_{2} s^{2}+A_{1} s+A_{0}\right)}
$$

ここで, $\quad A_{0} \equiv\left(\alpha_{s}+\alpha_{L}\right)\left\{2 w_{W} w_{W}\left(2 V_{A} w_{A}+\beta\right)+2 v_{A} w_{A} \beta\right\}+\alpha_{S} \alpha_{L}\left(2 w_{W} v_{W}+\beta\right)$,

$A_{1} \equiv C_{\text {Sheli }}\left\{2 v_{W} w_{W}\left(2 v_{A} w_{A}+B\right)+2 v_{A} w_{A} \beta\right\}+C_{W}\left(\alpha_{S}+\alpha_{L}\right)\left(2 v_{A} w_{A}+\beta\right)$

$$
+\alpha_{s}\left\{\alpha_{L} C_{W}+C_{\text {Sheil }}\left(2 v_{W} w_{W}+\beta\right)\right\} \text {, }
$$

$A_{2} \equiv C_{W} C_{\text {Shell }}\left\{\left(2 v_{A} w_{A} 2 v_{A} w_{A}+\beta\right)+\alpha_{S}\right\}$,

$B_{0} \equiv\left(\alpha_{s}+\alpha_{L}\right)\left\{2 v_{W} w_{W} \Delta \beta\left(\theta_{m s}-\varphi_{m s}\right)-2 \Delta v_{A} w_{A}\left(2 \Delta v_{W} w_{W}+\beta\right)\left(\varphi_{m s}-\varphi_{i}\right)\right\}$

$B_{1} \equiv C_{\text {She } 11}\left\{2 v_{A} w_{A} \Delta \beta\left(\theta_{m s}-\varphi_{m s}\right)-2 \Delta v_{A} w_{A}\left(2 v_{W} w_{W}+\beta\right)\left(\varphi_{m s}-\varphi_{i}\right)\right\}$

$+C_{W}\left(\alpha_{s}+\alpha_{L}\right)\left\{\Delta \beta\left(\theta_{m s}-\varphi_{m s}\right)-2 \Delta v_{A} w_{A}\left(\varphi_{m s}-\varphi_{i}\right)\right\}$,

$B_{2} \equiv C_{W} C_{\text {Shell }}\left\{\Delta \beta\left(\theta_{m s}-\varphi_{m s}\right)-2 \Delta v_{A} w_{A}\left(\varphi_{m s}-\varphi_{i}\right)\right\}$,

$$
\Delta \Theta_{1 n}(s)=\frac{D_{1} s+D_{0}}{s\left(A_{2} s^{2}+A_{1} s+A_{0}\right)}
$$

ここで, $\quad D_{0} \equiv\left(\alpha_{s}+\alpha_{L}\right)\left\{-2 v_{W} w_{W} \Delta \beta\left(\theta_{m s}-\varphi_{m s}\right)-2 \Delta v_{A} w_{m} \beta\left(\varphi_{m s}-\varphi_{i}\right)\right\}-\alpha_{s} \alpha_{L} \Delta \beta\left(\theta_{m s}-\varphi_{m s}\right)$,

$D_{1} \equiv C_{\text {She11 }}\left\{-2 v_{A} w_{A} \Delta \beta\left(\theta_{m s}-\varphi_{m s}\right)-2 \Delta v_{A} w_{A} \beta\left(\varphi_{m s}-\varphi_{i}\right)\right\}-\alpha_{s} C_{\text {She11 }} \Delta \beta\left(\theta_{m s}-\varphi_{m s}\right)$.

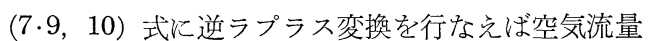
変化に対するステップ応答を求めることができる。こ

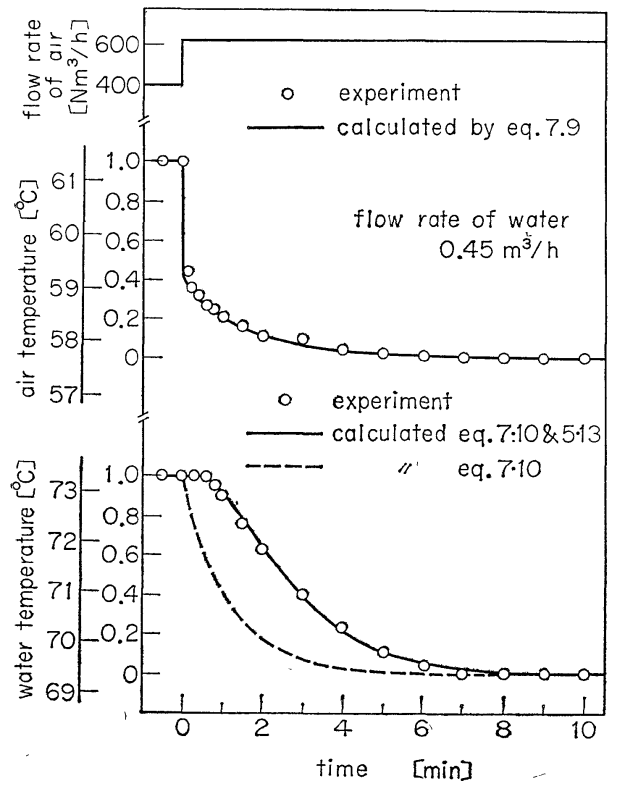

Fig. 9 Step response
の結果から理論応答曲線を求めた一例を Fig. 9 亿, 実験結果と比較して示す.

この結果を，「仮·6〕を用いた理論応答曲線と比較 すると，応答の収束時までかなりよい近似が觉られて いる。

以上の結果から，シェルと保温材の熱容量を考慮し， さらに動作点近傍で接線近似を行ない放熱量はシェル 内空気の温度と外気温度との差に比例するものとして 過渡特性を推定するならば，十分実験検証に耐える結 果を光ることができる、しかし応答の初期については， シェルと保温材の熱容量を無視し放熱量を一定として も大きな差異はない。

〔補〕従来, 流量変化に対する過渡特性を推定するに は線形化の手法が用いられる．線形化の手法を適 用したときの伝達関数は，いままで求めた忘答式 を変形することにより容易に求められるたたと兄 ば，集中・集中定数系のモデルに乱ける空気流量 変化汇対与る伝達関数(線形化の手法を適用して) は，つぎのように求められる。

熱通過率は[仮·6]により $\beta=\beta_{s}+\left(\partial \beta / \partial v_{m}\right) \Delta v_{A}$ のように変化するとすれば, 
(6.4) 式から,

$$
\frac{\Delta \Phi_{m}(s)}{\Delta v_{A}(s)}=\frac{C A^{\prime} s+2 \alpha v_{W} w_{W}\left(\theta_{m s}-\varphi_{m s}\right)-2 w_{A}\left(2 v_{W} w_{W}+\beta s\right)\left(\varphi_{m s}-\varphi_{i}\right)}{C\left(2 v_{A} w_{A}+\beta_{s}\right) s+2 v_{W} w_{W}\left(2 v_{A} w_{A}+\beta\right)+2 v_{A} w_{A} \beta}
$$

ここに, $A^{\prime} \equiv \alpha\left(\theta_{m s}-\varphi_{m s}\right)-2 w_{A}\left(\varphi_{m s}-\varphi_{i}\right)$ $\alpha \equiv\left(\partial \beta / \partial v_{A}\right)$ (Fig. 2 から求まる).

となる。

\section{8. あとがき}

シェル・アンド・チューブ式熱交換器の相変化をと もなわない一形態について, 温水流量および空気流量 変化に対するステップ応答を中心に，過渡特性に関す る実験的研究の結果について抄述した。

シェル・アンド・チューブ式熱交換器について, 温 水流量特よび空気流量変化に対する出口温度のステッ プ応答を実験で求めた。

いくつかの仮定にたって，(1) 空気側集中, 温水側 分布定数系，(2) 両者を集中定数系としたモデルにつ いて，かなり理論的にステップ応答の算出を試みた。

この結果を実験結果と比較してみると,シェルと保 温材の熱容量を考慮し放熱量はシェル内空気温度と外 気温度との差に比例するものとして取り扱光ば，応答 の収束する部分までかなりよい近似が兄られる。シェ ルと保温材の熱容量が添か江比して小さいときには, その熱容量を無視し放熱量を一定として応答を推定し ても, 応答の初期に限孔ば一応満足すべき近似が元ら
れる。

ステップ応答に関して, 熱交換器の構造定数および 一般的稼動特性から近似の伝達関数を導くことができ れば便利である。理論的なステップ応答を適宜簡単化 することにより，この近似伝達関数を求めることがで きよう。しかし，実際に使用する場合，目的などによ って近似の精度を異にするものであるから，ここでは 簡単化には触れない。

今後, 熱交換器の相変化をともなう場合の過渡特性 へと研究を展開していく予定である。

終わりに，この実験を支援してくださった古河電気 工業株式会社・大阪伸銅所の方々ならびに森田佐一郎 君はじめ早大理工学研究所・制御工学研究室の各位に 厚く就を礼をし上げる。

\section{参考文 献}

1）たと党ば，增淵正美：熱交換器の動特 性，日本機械学 会誌，62-491，1728/1734 (1959)

2) Stermole, F. J. \& Larson, M. A. : I \& EC Fundamentals, 2-1, 62/67 (1963)

3) Koppel, L. B. : I \& EC Fundamentals, 1-2, 131/134 (1962)

4) 高橋安人：流量変化に対する熱交換器の応答，自動制 御，6-1，2/7 (1959) 